\title{
Application of weighted goal programming in the optimization of rations for sport horses
}

\author{
J. Prišenk1 , K. Pažek, Č. Rozman, J. Turk, M. Janžekovič and A. Borec \\ University of Maribor, Faculty of Agriculture and Life Sciences \\ Pivola 10, 2311 Hoče, Slovenia
}

KEY WORDS: feed ration balancing, modelling, linear and weighted goal programming

Received: 5 January 2012

Revised: 10 June 2013

Accepted: 25 October 2013

${ }^{1}$ Corresponding author: e-mail: jernej.prisenk@um.si
ABSTRACT. The objective of this study was to develop a model to assess economical and balanced feed rations for sport horses. It was based on nonparametric modelling with a combination of linear programming and a multiobjective optimization technique: weighted goal programming. The method incorporates multiple goals into optimization. The technical data presented the feed nutritional value (dry matter, metabolizable energy, metabolizable protein, etc.) and nutritional requirements, which were represented in weighted goal programming as targets. The model was tested for optimization of winter and summer feed rations, where summer feed rations are more expensive but more balanced. Optimization results show that the method of weighted goal programming is more accurate and useful in practice compared with linear programming, where only one goal (economically optimal feed rationing) is taken into account.

\section{Introduction}

Horse jumping is a sport that places physical and psychological burdens on the animal (Janžekovič et al., 2010; Prišenk, 2010). Consequently, it is of utmost importance to provide optimal feed rations to satisfy all daily requirements. Poorly balanced feed rations certainly affect the welfare of animals and can worsen their health, especially of those who are under constant psychological and physical pressure, such as sport horses. Studies (Zhang and Roush, 2002; Zimmermann, 2008; Oliveira et al., 2010; Žgajnar et al., 2010) have been conducted in the field of ruminant nutrition for production purposes, so it was a research challenge to condense the information on the development of mathematical methods in animals that experience high levels of competitive stress.
Composing the appropriate feed rations for sport horses is demanding and complex from a behavioural and nutritional perspective. Appropriate portions of the compounds are also very important from an economic perspective, because feed costs amount to up to $55 \%$ or more of total variable costs on a farm (Žgajnar et al., 2009). Finding low-cost feed compound combinations is a standard optimization problem (Brus et al., 2006).

The application of mathematical approaches (mathematical programming) in the feed industry is not new. This is confirmed by a literature review, where numerous examples of different mathematical methods to solve either optimal animal or human nutrition problems can be found (Harris and Bishop, 2007; Babić and Perić, 2011). On the one hand, traditionally, the feed industry has been focused on 
optimal feeds for nutritional requirements in different situations, considering the type and amount of roughage, and the type of horse. On the other hand, some kinds of feeds do not take into account any roughage, which is the reason for their low cost. Nonetheless, the most commonly used method for developing the cheapest and most balanced feed rations is linear programming (LP), which was first used by Waugh (1951).

As noted by Castrodeza et al. (2005), LP has been the most commonly used technique in assembling meals for animals. The model was composed especially for winter and the annual instalment, and separately for each feeding period by the average weight of animals. The shortcomings of LP have been pointed out by many authors, however (Rehman and Romero, 1984; Gass, 1987; Tamiz et al., 1998). The greatest weaknesses are reflected in the rigidity of the limit (where the limits are fixed) and in allowing optimization of only one objective at a time. In many situations LP has no feasible solution. The most used technique for solving these problems is goal programming, in particular, weighted goal programming (WGP) (Tamiz et al., 1998). Agricultural applications of WGP are presented by Rehman and Romero (1987), Lara (1993), GómezLimón et al. (2004), Ferguson et al. (2006), Stokes and Tozer (2007), Zimmerman (2008), Žgajnar et al. $(2009,2010)$. The aim of this paper is to use the developed model for the optimization of feed rations for sport horses with a combination of linear and weighted goal programming and, further, to present the advantages of weighted goal programming. Our hypothesis is based on the presumption that feed ration optimization with WGP will be more expensive, but considerably more balanced than LP.

\section{Material and methods}

\section{Model development}

The model was developed in steps (Žgajnar et al., 2010) and has two sub-models (Figure 1). The first sub-model is classic LP, which calculates an indicative assessment of the least expensive feed, while the second sub-model represents WGP, which gives the final feed equation. LP has a single objective function, which is to minimize the total cost of feed, assuming the objective of ensuring that all restrictions are met. The main difference between the LP and WGP methods is in the number of optimized objectives. Restrictions in the LP programme were defined with signs like higher or lower (' $<$ ' or ' $>$ '). The restrictions mostly deal with nutritional standards, but they must be well structured to meet the type of diet required. LP is frequently not suitable for practical use because of excessive deviations from optimal feed rations. For solving these problems, the previously set limits were reconstructed in the objectives (restrictions with signs ' $<$ ' or ' $>$ ' were replaced with objectives having the $=$ sign).

In WGP, objectives are limited by deviations in the positive and negative direction to the tolerance of the target. This mathematical model has a single objective function that minimizes deviations from the targets. It is crucial to use a 'normalization' technique for deviations, because of different measurement units, which convert them into comparable items and can facilitate further calculations. With this process, all deviations are expressed as a ration difference [i.e. $($ desired-actual $) /$ desired $)=($ deviation)/desired)] (Žgajnar et al., 2010). A major issue of debate within the GP community has concerned the use of normalization techniques to overcome incommensurability (Tamiz et al., 1998).

With 'hanging' weights $(w)$ on a single target, a hierarchical scale is created and 'punishes' unwanted deviation from target values. The penalty function (PF) is defined with a minimum and maximum tolerance interval for each goal. Sensitivity of the PF is dependent on the number and size of the defined intervals and the penalty scale utilized (Žgajnar et al., 2009).

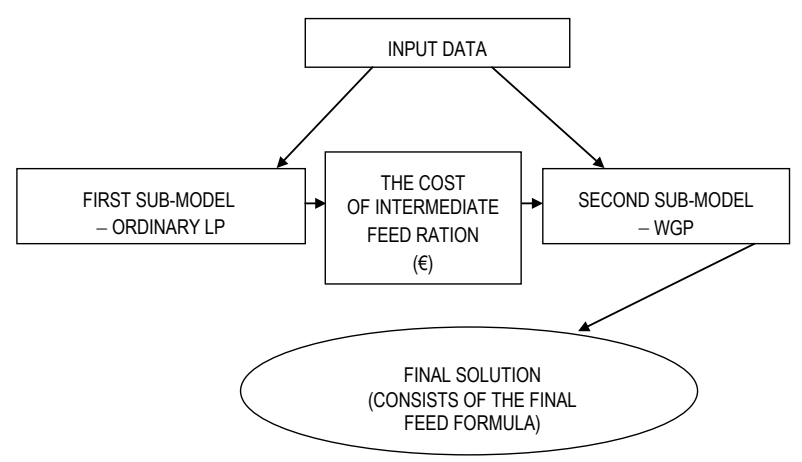

Figure 1. Scheme of the optimization model

The first sub-model is a simple LP model (equations from 1 to 3 ). The first and second equations represent the framework of the first sub-model (also defined as basic formulas), while the third represents the restrictions of the model. LP minimizes the cost of feed and represents a sum of multiplications between price and quantity of each type of compound included in the feed ration. The minimum cost of a feed ration (1) is also the one and only goal in the LP formulation target function. The model also includes the limits that have taken into account the composition of feed and referred to no 
tolerance levels of individual norms in the daily needs of horses (2).

The mathematical formulation of LP (adapted by Žgajnar et al., 2010):

$$
\begin{gathered}
\min C=\sum_{f=1}^{l} C_{f} \times X_{f} \\
\sum_{f=1}^{l} H_{k f} \times X_{f} \leq R_{i}
\end{gathered}
$$

for all $k$ to $o$

$$
X_{f} \geq 0
$$

for all $f$

where: $H_{k f}$ - the quantity of $k$-th nutrient in one unit of $f$-th feed type at disposal $\left(\mathrm{kg} \cdot \mathrm{kg}^{-1}\right.$ of pattern); $X_{f}$ - the quantity of the $f$-th feed type at disposal in the feed ration $(\mathrm{kg}) ; C_{f}$ - costs of $f$-th feed type at disposal $\left(€ \cdot \mathrm{kg}^{-1}\right) ; R_{i}-$ the amount of the $i$-th daily nutritional requirements of horses (DM, ME, MP, $\mathrm{Ca}, \mathrm{P})(\mathrm{kg}, \mathrm{MJ}$ and $\mathrm{g}) ; f$ - feed type at disposal; $f$ to $l$-seven feed types at disposal; $k$ to $o$ - five different types of nutrients.

In the mathematical formulation of WGP, limitations were changed through the objectives. Compared with the LP, WGP is based on the four basic formulas $(4,5 \mathrm{~A}, 5 \mathrm{~B}$, and 6$)$, while other equations represent the restrictions and other supported tools. This has set a large number of targets and minimized the sum of deviations from targets (a target function (4)). The mathematical formulation of the latter model (WGP) is written by equations from 4 to 10 (adapted by Žgajnar et al., 2010):

$$
\begin{gathered}
\min \mathrm{E}=p c_{1} \quad \sum_{k=1}^{l} w_{k} \frac{d_{k 1}{ }^{-}+d_{k 1}{ }^{+}}{g_{k}} \\
+p c_{2} \sum_{k=1}^{l} w_{k} \frac{d_{k 1}{ }^{-} d_{k 2}{ }^{+}}{g_{k}} \\
g_{k}=\sum_{f=1}^{l} H_{k f} \times X_{f}+d_{k 1}{ }^{-}+d_{k 2}{ }^{-}-d_{k 1}{ }^{+}-d_{k 2}{ }^{+}
\end{gathered}
$$

for all $k$ to $o$ and $g_{k} \neq 0$

$$
\begin{gathered}
C=\sum_{f=1}^{l} C_{f} \times X_{f}+d_{1}^{-}+d_{2}^{-}-d_{1}^{+}-d_{2}^{+} \\
\mathrm{C} \neq 0 \\
\sum_{f=1}^{l} H_{k f} \times X_{f} \leq R_{i}
\end{gathered}
$$

for all $k$ to $o$

$$
\sum_{f=1}^{l} H_{k f} \times X_{f}=g_{k}
$$

for all $k$ to $o$ and $g_{k}=0$

$$
d_{k 1}{ }^{-} \leq g_{k}-p_{k 1}{ }^{\min } g_{k}
$$

for all $k$ to $o$

$$
d_{k 1}{ }^{-}+d_{k 3}{ }^{-} \leq g_{k}-p_{k 2}{ }^{\min } g_{k}
$$

for all $k$ to $o$

$$
d_{k 1}^{+} \leq p_{k 1}{ }^{\max } g_{k}-g_{k}
$$

for all $k$ to $o$

$$
d_{k 1}{ }^{+} d_{k 2}{ }^{+} \leq p_{k 1}{ }^{\max } g_{k}-g_{k}
$$

for all $k$ to $o$

$$
d_{k 1}{ }^{+}, d_{k 1}{ }^{-}, d_{k 2}{ }^{+} d_{k 2}{ }^{-}, X_{f} \geq 0
$$

where: $g_{k}$ - expected daily requirement of the $k$-th nutrient (objectives - goals); $d_{k 1}{ }^{+}, d_{k 1}{ }^{-}, d_{k 2}{ }^{+} d_{k 2}{ }^{-}$ intervals of positive and negative deviations from goals; $p c_{1}, p c_{2}-$ penalty coefficients; $p_{k 1}{ }^{\min }<100 \%$, $p_{k 1}{ }^{\max }>100 \%$ - defined penalty function parameters for the first interval deviation from the nutrient requirements; $p_{k 2}{ }^{{ }^{\min }<100 \%}, p_{k 2}{ }^{\max }>100 \%$ - defined penalty function parameters for the second interval deviation from the nutrient requirements.

The target function is presented by equation 4 , which minimizes the sum of deviations from targets or goals themselves, as the LP. As a part of the objective function, there are penalty coefficients $\left(p c_{1}=2\right.$ and $\left.p c_{2}=4\right)$ with constant values in first and second interval deviations from nutrients. The values of penalty coefficients were deterministic, determined after the definition of PF (parameters), and extended the penalty function as the product between $w_{k}$ and $p c$ (adapted from Romero and Rehman, 2003). The result obtained is highly dependent on specific weights, which may have a value between 0 and 100 . The objectives that we defined in the latter model are represented with equations $5 \mathrm{~A}$ and $5 \mathrm{~B}$. Any deviation, which must lie within the set of intervals, is examined with equations $8 \mathrm{~A}, 8 \mathrm{~B}, 9 \mathrm{~A}$ and $9 \mathrm{~B}$.

\section{Model input data}

Model input data is data of the daily needs of horses with regards to nutrients and minerals, as well as the level of nutrients and minerals in each type of feed (Table 1). The upper section of Table 1 represents the summer and the winter nutrition requirements of sport horses; and the lower part of Table 1 represents the nutritive value of feed at disposal. 
Table 1. Feed standards and nutritional value of available feed (according to Frape, 2010)

\begin{tabular}{|c|c|c|c|c|c|c|}
\hline & \multicolumn{5}{|c|}{ Feed standards-winter } & \\
\hline & $\mathrm{DM}^{1}$ & $\mathrm{ME}^{1}$ & $\mathrm{MP}^{1}$ & $\mathrm{Ca}^{1}$ & $\mathrm{P}^{1}$ & \\
\hline Weight of horse $(550-600 \mathrm{~kg})$ & 14 & 126.2 & 1207 & 36 & 26 & \\
\hline Unit & $\mathrm{kg} \cdot \mathrm{day}^{-1}$ & $\mathrm{MJ} \cdot$ day $^{-1}$ & $g \cdot$ day $^{-1}$ & $g \cdot$ day $^{-1}$ & $g \cdot$ day $^{-1}$ & \\
\hline $\begin{array}{l}\text { Feed standards - Summer } \\
\text { weight of horse }(550-600 \mathrm{~kg})\end{array}$ & 13.5 & 134.7 & 1448 & 44 & 32 & \\
\hline Unit & $\mathrm{kg} \cdot$ day $^{-1}$ & MJ $\cdot$ day $^{-1}$ & $\mathrm{~kg} \cdot$ day $^{-1}$ & $\mathrm{~kg} \cdot$ day $^{-1}$ & $\mathrm{~kg} \cdot$ day $^{-1}$ & \\
\hline Nutrients & & & & & & \\
\hline feed at disposal & DM & ME & MP & $\mathrm{Ca}$ & $P$ & Price \\
\hline hay & 860 & 7.4 & 80 & 2.9 & 1.7 & 0.158 \\
\hline grass silage & 350 & 5.6 & 62 & 6 & 2.2 & 0.06 \\
\hline grain maize & 880 & 14.2 & 85 & 0.2 & 3 & 0.17 \\
\hline barley & 880 & 12.8 & 95 & 0.6 & 3.3 & 0.151 \\
\hline oats & 880 & 12.1 & 96 & 0.7 & 3 & 0.16 \\
\hline wheat & 860 & 14.2 & 100 & 0.4 & 3.2 & 0.134 \\
\hline Endurix Cavalor & 880 & 16.39 & 122 & 7.5 & 5.8 & 0.71 \\
\hline Unit & $\mathrm{g} \cdot \mathrm{kg}^{-1}$ & $\mathrm{MJ} \cdot \mathrm{kg}^{-1}$ & $\mathrm{~g} \cdot \mathrm{kg}^{-1}$ & $\mathrm{~g} \cdot \mathrm{kg}^{-1}$ & $\mathrm{~g} \cdot \mathrm{kg}^{-1}$ & $€ \cdot \mathrm{kg}^{-1}$ \\
\hline
\end{tabular}

${ }^{1} \mathrm{DM}$ - dry matter; ME - metabolizable energy; MP - metabolizable protein; $\mathrm{Ca}$ - calcium; $\mathrm{P}$ - phosphorus

Daily requirements of sport horses (for example jumping horses) vary between summer and winter rations, especially because of training intensity, which is higher during the competition season (between May and September). Because of the different competition periods in different countries, the summer and winter rations could be renamed as rations during and out of competition season. Considering the literature (Frape, 2010), the winter nutritional standards (light training intensity) are higher in comparison with summer requirements (moderate to higher training intensity). According to Salaić et al. (2010), during the intensive training season the concentration of glycogen in muscles is raised up to $130-150 \mathrm{mmol} \cdot \mathrm{kg}^{-1}$ body weight. Consequently, the quantity of available glucose in the blood is dependent on the concentration of glycogen and represents the success of sport horses (Geor, 2007). Therefore, the rations must always be in line with the current needs of horses, which could change daily. Feeding the 'sport' rations should start 8-12 weeks before the intensive training activity (Salaić et al., 2010).

Furthermore, special emphasis in the composition of feed rations is given to the selection of high-quality, reliable and accurate input data (norms, nutrients and minerals in each type of feed, the prices of individual products, etc.). In the daily compilation of animal feed rations, it is necessary to consider the available quantity of each feed. This is why the second sub-model includes additional restrictions in the form of the relationship between calcium and phosphorus. The feed ration must not exceed $5 \mathrm{~kg}$ of dry feed and $20 \mathrm{~kg}$ of grass silage and hay (Frape, 2010).
The input data also contains a set of norms and deviations from the set of goals (Table 2). The hierarchical scale (setting the standards that were given priority) was created by using the set of weights (w). Three simulations were run for each type of diet. In the first simulation, the price of feed has a higher weight compared with the others. The size of the tolerance interval was determined according to the importance of achieving this objective. The composite feed meal is the most important item to satisfy the needs for energy and protein, so in this case, the narrowest interval deviations are 3\% and $10 \%$, respectively. These two objectives, therefore, have higher weights. A tolerance interval for dry matter was not set up $\left(p_{1}+\right.$ and $\left.p_{2}+=0\right)$, because it represents the consumption capacity of animals, i.e. the amount of feed that the animal is able to consume in one day. Intervals for the costs of the feed ration were not defined $\left(p_{1}-\right.$ and $\left.p_{2^{-}}=\infty\right)$. It is contradictory to limit the cost of feed in a negative direction, because the main aim is to draw up the least expensive diet meal feed.

Three simulations were performed. In the first, the cost of feed had higher weights (WGPw1 and WGPs1) ( $\mathrm{w}=100)$ compared with the second simulation (WGPw2 and WGPs2), where the cost of feed did not play a major role $(\mathrm{w}=10)$. In simulation 3, the weight of feed had a value of 50. The complex WGP also includes the ratio between calcium and phosphorus $(\mathrm{Ca}: \mathrm{P}=2: 1)$, which is very important in horse nutrition. Otherwise, the proportion between $\mathrm{Ca}$ and $\mathrm{P}$ could have a strong negative effect on all occurrences in the organism. 
Table 2. Daily winter and summer requirement of sports horses (550-600 kg), shown as restriction (LP) or set goals (WGP), and parameters of penalty functions

\begin{tabular}{|c|c|c|c|c|c|c|c|c|c|}
\hline \multirow[t]{3}{*}{ Indices } & \multirow{2}{*}{\multicolumn{2}{|c|}{ Winter }} & \multirow{2}{*}{\multicolumn{2}{|c|}{ Summer }} & \multicolumn{4}{|c|}{ Penalty function/PF, \% } & \multirow{3}{*}{$\begin{array}{l}\text { Weight } \\
\mathrm{w}_{\mathrm{k}}^{*}\left(\mathrm{w}_{\mathrm{h}}^{* *}\right)\end{array}$} \\
\hline & & & & & \multicolumn{2}{|c|}{ interval 1} & \multicolumn{2}{|c|}{ interval 2} & \\
\hline & $\mathrm{LP}_{\mathrm{w}}$ & $\mathrm{WGP}_{\mathrm{w}}$ & $\mathrm{LP}_{\mathrm{S}}$ & $W_{G P}$ & $\overline{p_{i}}$ & $p_{1}^{+}$ & $p_{2}^{-}$ & $p_{2}^{+}$ & \\
\hline $\mathrm{DM}, \mathrm{kg}$ & $<14$ & 14 & $<13.5$ & 13.5 & 5 & 0 & 15 & 0 & $40(70)$ \\
\hline ME, MJ & $>126.2$ & 126.2 & $>134.7$ & 134.7 & 3 & 3 & 10 & 10 & $100(80)$ \\
\hline MP, g & $>1207$ & 1207 & $>1448$ & 1448 & 3 & 3 & 10 & 10 & $70(80)$ \\
\hline $\mathrm{Ca}, \mathrm{g}$ & $>37$ & 37 & $>44$ & 44 & 5 & 5 & 20 & 20 & $5(80)$ \\
\hline$P, g$ & $>26$ & 26 & $>32$ & 32 & 5 & 5 & 20 & 20 & $5(80)$ \\
\hline Cost, $€$ & & C & & C & $\infty$ & 10 & $\infty$ & 20 & $10 / 100(50)$ \\
\hline \multicolumn{10}{|l|}{ Feed restrictions } \\
\hline Ca:P & & $2: 1$ & $2: 1$ & & & & & & \\
\hline $\min$ dry feed, $\mathrm{kg} \cdot$ day $^{-1}$ & & 2 & 2 & & & & & & \\
\hline $\max$ dry feed, $\mathrm{kg} \cdot$ day $^{-1}$ & & 5 & 5 & & & & & & \\
\hline max hay + grass silage, $\mathrm{kg} \cdot$ day $^{-1}$ & & $<20$ & $<20$ & & & & & & \\
\hline
\end{tabular}

* weights for $\mathrm{WGP}_{\mathrm{w} / \mathrm{s} 1}$ and $\mathrm{WGP}_{\mathrm{w} / \mathrm{s} 2}{ }^{* *}$ weights for $\mathrm{WGP}_{\mathrm{w} / \mathrm{s} 3}$

Table 3. Calculated winter and summer daily feed ration using LP (the first sub-model) and WGP (second sub-model) for three simulations

\begin{tabular}{|c|c|c|c|c|c|c|c|c|}
\hline \multirow[t]{3}{*}{ Type of feed } & \multicolumn{8}{|c|}{ Daily ration } \\
\hline & \multicolumn{4}{|l|}{ winter } & \multicolumn{4}{|l|}{ summer } \\
\hline & $\mathrm{LP}_{\mathrm{w}}$ & $\mathrm{WGP}_{\mathrm{w} 1}$ & $\mathrm{WGP}_{\mathrm{w} 2}$ & $W \mathrm{WP}_{\mathrm{w} 3}$ & $\mathrm{LP}_{\mathrm{s}}$ & $\mathrm{WGP}_{\mathrm{s} 1}$ & $\mathrm{WGP}_{\mathrm{s} 2}$ & $\mathrm{WGP}_{\mathrm{s} 3}$ \\
\hline Hay, kg & 0 & 6.18 & 12.70 & 10.95 & 0.00 & 5.42 & 12.39 & 11.73 \\
\hline Grass silage, $\mathrm{kg}$ & 17.53 & 3.02 & 0 & 0.82 & 20.00 & 4.45 & 1.21 & 1.51 \\
\hline Grain maize, kg & 1.22 & 0.79 & 0.65 & 0.80 & 0.58 & 1.14 & 0.72 & 0.78 \\
\hline Barley, kg & 0.28 & 0.42 & 0 & 0 & 0.31 & 0.61 & 0.39 & 0.42 \\
\hline Oats, kg & 0 & 1.06 & 0.57 & 0.70 & 0.77 & 1.53 & 0.96 & 1.05 \\
\hline Wheat, kg & 0.50 & 0.76 & 0.40 & 0.50 & 0.55 & 1.09 & 0.69 & 0.75 \\
\hline Endurix Cavalor, kg & 0 & 0 & 0 & 0 & 0 & 0 & 0 & 0 \\
\hline Cost, $€ \cdot$ day $^{-1}$ & 1.37 & 1.37 & 2.00 & 1.84 & 1.54 & 1.54 & 2.19 & 2.15 \\
\hline Cost deviation, \% & & 0 & 46.37 & 34.20 & & 0 & 42.53 & 39.33 \\
\hline \multicolumn{9}{|c|}{ Deviation from daily requirements, $\%$} \\
\hline DM & -43.59 & -37.10 & -13.47 & -19.75 & -33.72 & -27.14 & -1.70 & -3.56 \\
\hline ME & 0.00 & -18.73 & -8.50 & -11.02 & -4.95 & -8.86 & 0.00 & 0.00 \\
\hline MP & +5.01 & +19.96 & +3.45 & -7.89 & 0.00 & +22.65 & +8.52 & -9.33 \\
\hline $\mathrm{Ca}$ & +185.99 & 0.00 & 0.00 & 0.00 & +175.15 & 0.00 & 0.00 & 0.00 \\
\hline $\mathrm{P}$ & +72.15 & 0.00 & 0.00 & 0.00 & +53.88 & 0.00 & -0.90 & 0.00 \\
\hline
\end{tabular}

${ }^{*}$ weights for $\mathrm{WGP}_{\mathrm{W} / \mathrm{S} 1}$ and $\mathrm{WGP}_{\mathrm{w} / \mathrm{s} 2}$;* , weights for $\mathrm{WGP}_{\mathrm{w} / \mathrm{s} 3}$

On the one hand, the crucial point of composing the rations for sport horses during the competition season is to compose 'light' rations as much as possible, which should be balanced between roughage and a higher need for metabolizable energy and protein (Salaić et al., 2010). On the other hand, rations should be composed in a way caring for animal welfare and without endangering animal health (where $0.5 \mathrm{~kg} \mathrm{DM} \cdot$ day $^{-1}$ does not have a negative impact on the animal's health status; according to Frape, 2010).

Table 2 represents the application of weighted goal programming developed in MS Office Excel using a software add-in, Solver (describe in Parsons et al., 2008). The rations are mixed using specially developed simulation models in an Excel spread sheet environment.

\section{Results}

The model was applied to the optimization of winter and summer feed rations for sport horses with body weights between 550 and $600 \mathrm{~kg}$. The model was improved in terms of small deviations from the required daily feed norms of horses, while the cost of feed remains unchanged (WGPw1 and WGPs1).

The compositions of the feed rations are given in Table 3. In the second simulation (WGPw2 and WGPs2), the costs of the feed rations have a smaller priority $(\mathrm{w}=10)$, consequently, the feed rations are more expensive.

The deviations (measured in percentages) from the daily nutrient requirements of horses and the cost deviation (between LP and WGP rations) are also presented in Table 3. In general, the results 
show that rations calculated using the WGP technique better satisfy all nutritional requirements [WGPs2 has the minimum deviation $(-1.7 \%)$ of DM from daily requirements in comparison with $\mathrm{LP}$, where the deviations are $-43 \%(\mathrm{LPw})$ or $-33 \%$ (LPs)]. The results of the third simulation (WGPs3 and WGPw3) showed that deviations from daily requirements and costs of feed are between the first and the second simulations (DM - WGPs1 $>$ WGPs3 > WGPs2; ME - WGPw1 > WGPw3 $>$ WGPw2; Costs - WGPs $1<$ WGPs3 $<$ WGPs2).

\section{Discussion}

The composition of feed rations is different between the two sub-models, as well as in both scenarios. Compared with WGP, the type of diet based on LP has diverged in relation to different norms for more than a total of $180 \%$, so this type of diet is not acceptable in practice. In $\mathrm{WGP}_{\mathrm{w} 2}$ and $\mathrm{WGP}_{\mathrm{s} 2}$ (simulation 2), deviations from standards have minimal values, but these rations are more expensive (by $46 \%$ and $42 \%$, respectively; Table 3 ). These are the important characteristics of the model, which allow compounding the same economically efficient ration that does not deviate from the least expensive one, but takes into account the nutrient requirements in the better way than LP. In simulation $1\left(\mathrm{WGP}_{\mathrm{w} 1}\right.$ and $\left.\mathrm{WGP}_{\mathrm{s} 1}\right)$, WGP calculated a feed combination that deviates from the minimum standards by $15 \%$ to $30 \%$. It can be predicted that better balanced feed rations (WGP meals) may not always be more expensive compared with meals calculated by LP, but these rations are not accepted in practice either (there is no roughage included in the ration). In simulation 2, the costs of meals did not play a major rule. These meals are more expensive, but they are balanced (only $8 \%$ deviations from MP and ME). Midway between feed costs and deviations from daily requirements are the results from simulation 3. These rations are more expensive in comparison with the first simulation results $(34.20 \%$ and $39.33 \%$ ) and less expensive in comparison with the second simulation results $(-12.17 \%$ and $-3.2 \%)$. The additional energy food product, Endurix Cavalor, was not included. Essential to the WGP is that all deviations are permitted within set interval variations, especially in the priority of goals (goals with the highest assigned weights). In the WGP solutions, grass silage was replaced by hay, which raised ration costs (since the production costs of hay are higher).

Nonetheless, the WGP rations in all scenarios produced better-balanced feed rations with respect to nutritional content. From a behavioural perspective, the latter is of the utmost importance as it gives the animals a feeling of satiety. Including the minimum roughage [1.5-2 $\mathrm{kg}$ roughage ( $88 \%$ dry matter)] is important not only in satisfying animals, but also from the aspect of their health. The WGP method was used and included hay into the ration. From this point of view, the crucial restrictions for upgrading the developed model should be including minimum roughage capacity or, as a minimum, 1.0- to 1.3fold of maintenance requirement in energy should presumably be derived from roughage.

\section{Conclusions}

A mathematical and software tool based on linear programming (LP) and weighted goal programming (WGP) was developed here. The tool provides decisive support for the assembly of feed rations for sport horses. WGP upgraded with penalty functions improved the individual elements of feed. In our case, the amount of calcium and phosphorus exceeded the recommended amount in the feed ration (surplus 70-180\%) and protein surplus (23\%) compared with the feed ration given with the LP, which may mean a significant deterioration in animal health. The costs of WGP-derived rations are, however, higher compared with LP.

As was already stated, similar mathematical techniques were successfully applied in the calculation of the rations for other animal species, but mixed rations were calculated with an accuracy of two decimal points of each feed at disposal. In practice, it is impossible to prepare the rations by including precisely $1.06 \mathrm{~kg}$ of oats, $0.76 \mathrm{~kg}$ of wheat, etc., but these can rounded off to one decimal point in practice. Using this kind of 'robust' data will not have a crucial impact on the higher price of rations, but there will be greater deviations from the restrictions (e.g., $+186 \%$ (LPw) or $+175 \%$ (LPs)) that do influence the higher ration price and health status of animals.

The added value of the represented methods could be recognized in the way that the decision maker is able to introduce any number of additional requirements that will be taken into account in the new output results.

\section{References}

Babić Z., Perić T., 2011. Optimization of livestock feed blend by use of goal programming. Int. J. Prod. Econ. 130, 218-223

Brus M., Rozman Č., Janžekovič M., 2006. Program application. What's best industrial in mathematical optimization of beef ration (in Croatian). In: S. Kapun, T. Čeh, I. Ambrožič (Editors). 
Conference publication of 15 . consultation on animal nutrition „Zadravčevi-Erjavčevi days". Chamber of Agriculture and Forestry of Slovenia, Agricultural and Forestry Institute, Murska Sobota, pp. 323-327

Castrodeza C., Lara P., Pena T., 2005. Multicriteria fractional model for feed formulation: economic, nutritional and environmental criteria. Agr. Syst. 86 (1), 76-96

Ferguson E.L., Darmon N., Fhmida U., Fitriyanti S., Harper T.B., Premachandra I.M., 2006. Design of optimal food-based complementary feeding recommendations and identification of key "Problem Nutrients" using goal programming. J. Nutr. 136, 2399-2404

Frape D.L. (Editor), 2010. Equine Nutrition and Feeding. $4^{\text {th }}$ Edition. Wiley-Blackwell, Chichester, pp. 496

Gass S., 1987. The setting of weights in linear goal-programming problems. Comp. Oper. Res. 14, 227-229

Geor R.J., 2007. Perspectives on feeding athletic horses in the $21^{\text {st }}$ century. Mid-Atlantic Nutrition Conference, Timonium, MD pp. $17-24$

Gómez-Limón J.A., Riesgo L., Arriaza M., 2004. Multi-criteria analysis of input use in agriculture. J. Agr. Econ. 55, 541-564

Harris P., Bishop R.E.M., 2007. Recent developments in equine nutrition and feeding. J. Roy. Agr. Soc. Engl. 168, 1-11

Janžekovič M., Prišenk, J., Muršec B., Vindiš P., Stajnko D., Čuš F., 2010. The art equipment for measuring the horse's heart rate. J. Achiev. Mater. Manuf. Eng. 41, 180-186

Lara P., 1993. Multiple objective fractional programming and livestock ration formulation: A case study for dairy cow diets in Spain. Agr. Syst. 41, 321-334

Oliveira J.E.G., Soares J.B., Barioni L.G., Leite G.G., Braga A.C., Menezes M.E., 2010. Optimized feed planning for a grazing horse production systems. R. Bras. Zootec. 39, 932-940

Parsons J.J., Oja D., Ageloff R., Carey P., 2008. New Perspectives: Microsoft Office Excel 2007; Comprehensive. Thomson Course Technology (USA), pp. 824
Prišenk J., 2010. Heart rate monitoring by non-invasive method in sport horses and development of the linear model for calculation of the horse fodder. B.Sc. Thesis. University of Maribor, Faculty of Agriculture and Life Sciences, pp. 64

Rehman T., Romero C., 1984. Multiple-criteria decision making techniques and their role in livestock ration formulation. Agr. Syst. $15,23-49$

Rehman T., Romero C., 1987. Goal programming with penalty functions and livestock ration formulation. Agr. Syst. 23, 117-132

Romero C., Rehman T., 2003. Multiple Criteria Analysis for Agricultural Decisions. $2^{\text {nd }}$ Edition. Elsevier, Amsterdam

Salaić J., Baban M., Domaćinović M., Mijić P., Sakač M., Bobič T., Budimir K., 2010. Comparison of the nutritional value of feed rations for sport horses in harness discipline (in Croatian). Stočarstvo 64, 29-39

Stokes J.R., Tozer P.R., 2007. Cost minimization and managing soil nutrient loading: Conflict or compromise? Can. J. Agr. Econ. 50, 151-169

Tamiz M., Jones D., Romero C., 1998. Goal programming for decision making: An overview of the current state-of-the-art. Eur. J. Oper. Res. 111, 569-581

Waugh F.V., 1951. The minimum-cost dairy feed. J. Farm Econ. 33, 299-310

Zhang F., Roush W.B., 2002. Multiple-objective (goal) programming model for feed formulation: An example for reducing nutrient variation. Poultry Sci. 81, 182-192

Zimmermann A., 2008. Optimization of sustainable dairy-cow feeding systems with an economic-ecological LP farm model using various optimization processes. J. Sustain. Agr. 32 (1), 77-94

Žgajnar J., Erjavec E., Kavčič S., 2010. Multi-step beef ration optimisation: application of linear and weighted goal programming with a penalty function. Agr. Food Sci. 19, 193-206

Žgajnar J., Juvančič L., Kavčič S., 2009. Combination of linear and weighted goal programming with penalty function in optimisation of a daily dairy cow ration. Agric. Econ. 55, 492-500 